\title{
Andrea Goótšová
}

Uniwersytet Śląski w Katowicach

\section{Banícka a hutnícka tradícia na Spiši a jej reflexia v hydronymách povodia Hornádu}

\section{Historický vývoj stredného a dolného Spiša}

Počiatky osídlenia opisovaného územia siahajú až do doby kamennej a bronzovej, o čom svedčia mnohé archeologické nálezy (Hrádok v Gánovciach, lokalita Čingov v Slovenskom raji, opevnené sídlo Myšia hôrka v katastri Spišský Štvrtok, osady Nálepkovo, Švedlár, Mníšek nad Hnilcom, chotár obce Odorín, lokalita Dreveník pri Spišskom hrade pamiatky v Medvedej jaskyni pri Ružíne, lokality Nižná Myšl'a, Barca, Pol'ov, Šebastovce pri Košiciach). Z hl'adiska hl'adania motivantov hydroným je pre nás určujúce poznanie, že už v závere doby kamennej sa obyvatelia Spiša dostali do styku s výdobytkami vtedajšieho poznania t’ažby, spracovania a využívania medi. Objav kovu sa v plnej miere prejavil v dobe bronzovej, ktorého spracovanie a výrobu, najmä železa, zdokonalila kultúra Keltov ${ }^{1}$, ktorá sa tu dostala do kontaktu so starším domorodým osídlením, obyvatel'mi púchovskej kultúry. Pre nich bola príznačná t’ažba a spracovanie rúd, hlavne železa a striebra, ktorými oplývala najmä oblast' Volovských vrchov, ako jedna z najbohatších zdrojov medenej rudy. A práve vynález železa, spadajúceho do obdobia staršej doby železnej, sa v tomto prostredí, podl'a interpretácií antických správ, pripisuje keltskému kmeňu Kotínov, ktorý tiež vedel t'ažit' a spracúvat' železnú rudu z povrchových ložísk [Budinský-Krička 1965]. Najmä oblast' Spiša sa stáva od 5. storočia významným metalurgickým regiónom, v ktorom jednoznačne dominovala výroba a spracovanie železa. Od Kotínov sa potom dolovaniu železnej rudy a výrobe železa priučili aj Sarmati a Kvádi, ako aj Slovania, čo sa následne prejavilo aj v mnohých toponymických pomenovaniach. Detailnejšie

1 Táto kultúra sa sem dostala po hornádskej ceste ( $\mathrm{K}$ tejto problematike pozri bližšie: Pastor 1955: 122-144; Furmánek1991: 53-81; Pravek východného Slovenska 1965. 
a dôkladnejšie mapovanie vývoja baníctva však nie je možné v dôsledku nedostatku písomných dôkazov ${ }^{2}$. Konkrétnejšie svedectvá sú až za vlády panovníkov Arpádovcov, ktorí sem povolávali remeselníkov a baníkov z Nemecka. Tí sem prišli v roku 1030 počas panovania uhorského krála Štefana I. Významnejší posun nastal s príchodom nemeckých kolonistov za panovníka Bela II. a Gejzu II., čo napomohlo, ako uvádza J. Bartalský [1993: 15], zmodernizovat' „prabaníctvo a prahutníctvo“ keltskej a vel'komoravskej éry a zvýšilo produkciu medi, striebra, zlata a železa. Zaviedla sa technika razenia štôlní „Schlägel und Eisen“, nie ohňom a vodou.

Príchodom tejto etnickej skupiny z oblasti Bavorska, Durínska a Porýnia do údolia Hnilca nastal po tatárskom vpáde rozmach banského podnikania ako následok obrovského dopytu po rudách. Táto skutočnost' podnietila najmä vznik nových sídel a hl'adanie nových ložísk. A práve bohaté ložiská Volovských vrchov sa stali týmto centrom, pretože vytvárali vhodné podmienky na rozvoj banského podnikania. Údolie Hnilca predstavovalo druhú banícku oblast' na Slovensku, kde je banská činnost' doložená ešte pred príchodom Tatárov [Pöss 2000]. Na území Spiša sa tak vytvorilo popri spišskej a saskej provincii v doline Hnilca spoločenstvo baníckych obcí, ktorých centrom sa stala Gelnica ${ }^{3}$. V 14. storočí sa pôsobnost' gelnického banského práva vzt'ahovala na niekol'ko banských obcí (Žakarovce, Folkmár, Jaklovce, Margecany, Prakovce, Helcmanovce, Mníšek nad Hnilcom, Švedlár a Slovinky). V roku 1487 si väčšie banské strediská vytvorili Zväzok siedmich hornouhorských banských miest, ktoré vypracovali štatút banského práva a súdnictva, pričom sa za určujúce záväzne prijalo gelnické banské právo.

\section{Súvislost' baníckej a hutníckej tradície pri tvorení hydroným}

Dlhodobá tradícia baníctva a hutníctva, ako aj príchod nemeckých remeselníkov, sa v danej oblasti prejavili aj pri tvorení názvov vodných tokov. Či už išlo o pôvodne slovanský (slovenský) názov, alebo o jeho inojazyčný, predovšetkým nemecký variant, nachádzame $\mathrm{v}$ tejto oblasti niekol'ko príkladov na jeho podloženie. Ilustrujúcim príkladom je hydronymum Smolník, ktorého etymológiou sa zaoberali viacerí (ne)lingvisti, no predostreli rôznorodé východiská. V. Šmilauer [1932: 401] vo Vodopise starého Uhorska uvádza pre vodný tok doklady

${ }^{2}$ Aj napriek tomu J. Bartalský [1993: 13], uvádza, že už v tom čase sa t’ažili rudy na východoch početných žíl v okolí Novoveskej Huty, Hnilčíka, Rudnian, Poráča, Sloviniek, Žakaroviec, Gelnice, Hnilca, Švedlára, Starej Vody, Mníška nad Hnilcom, Prakoviec, Tichej Vody, Mlynkov a Dobšinej.

${ }^{3}$ Gelnica ako stredisko hornouhorského baníctva mala pôvodne svoje vlastné gelnické právo, ktorého stopy boli nájdené v gelnickom banskom práve z XV. storočia V roku 1327 bolo Gelničanom nanútené štiavnické banské právo (pozri bližšie: Rešovský a kol. 2010: 16-18). 
Szmolnynk, Szmolnyk, Sumulnuk, Sumulnuch, Zumulnukfew (< nem. e Schmelzung - tavenie/topenie), pričom svoj výklad podopiera skutočnost'ou, že Gelničania v Smolníku tavili rudu. Iný pohl’ad ponúka P. Ratkoš [1979: 77] ked’ tvrdí, že názov toku Smolnik je odvodený od slova smoa, ktorou oplývali tunajšie lesy. Sotva však možno mysliet' na výrobu dechtu, v starých časoch tiež nazývaného smolou. Názov potoka Smolník vyjadroval podl'a neho farbu vody - tmavšiu a Hnilec - svetlejšiu (mal ílovitý ráz a hlinastú farbu). P. Ratkoš [1977] svoj názor poukázal na príkladoch: Čierny a Biely Váh, Čierny a Biely Hron, Čierna a Biela Orava a pod. Tvrdil tiež, že prv než vznikla osada Smolník, potok sa nazýval Smolník, resp. Smolnica. V hungarizovanej podobe Sumulnuch sa zachoval prvý písomný záznam tohto názvu $\mathrm{v}$ listine $\mathrm{z}$ roku 1243, pričom s týmto dátumom sa začínajú aj prvé stopy po vlastných dejinách Smolníka. Analýza uvedeného názvu stála v centre pozornosti aj B. Varsika [1990: 127], ktorý v monografii Slovanské (slovenské) názvy riek na Slovensku určil, že názov rieky Smolník je slovanského pôvodu a pochádza zo slova smola. B. Varsik [1990] uvádza, že prichádzajúci Mad’ari prevzali názov priamo od Slovanov, ked' s ním prišli do kontaktu už v 12. storočí, pri prenikaní do horného toku rieky Slanej na Spiš. Názov prešiel prirodzeným vývinom do mad'arčiny: Smolnik $>$ mad'. Szmulnuk $>$ Szumulnuk. Nemci prevzali názov priamo od Slovanov, adaptovali ho po formálnej stránke a vytvorili variant Schmölnitz Bach $(<$ nem. schmelzen - topit', tavit' rudu $+r$ Bach - potok), ktoré súviselo s t’ažbou a dolovaním rúd. Názov Smolník a jeho inojazyčné doklady Schmöllnitz, Szomolnokbánya majú tak slovansko-slovenský základ. Práve nemecké znenie môže byt' východiskom pri určení starého základu, ktorým sa označovali vody. Napokon R. Krajčovič [2005: 172] v monografii Živé kroniky slovenských dejín skryté v názvoch obcí a miest zastáva názor, že názov toku Smolnik je utvorený od apelatíva (apel.) smola s príponou -(n)ik, t.j. podla miesta, kde sa vyrábala smola. Zo záznamov zložených s prídavkom baňa je zrejmé, že smolu obyvatelia Smolníka vyrábali pre potreby baníkov hlavne na výrobu smolníc, smolných fakiel' na osvetlenie podzemných banských chodieb a podzemného pracoviska baníkov. V stredoveku sa totiž len vel'mi t’ažko dalo pracovat' bez smolných fakiel'. Ak by sme mali následne vyjadrit' vlastné stanovisko k pertraktovanej problematike, domnievame sa, že hydronymum Smolník nevzniklo z apel. smola + príponou miesta -(n)ík, pretože človek vyrábajúci, resp. pracujúci so smolou sa nenazýval smolnik a dané apelatívum ani nie je doložené $\mathrm{v}$ žiadnych listinách či historických lexikografických dielach. $\mathrm{Z}$ toho dôvodu tu nemožno nachádzat' zhodnú paralelu s názvom pekelník (< apel. peklo + činitel'ská prípona -(n)ik), lebo daný výraz je dochovaný v listine z roku 1055 a poukazuje na človeka, ktorý vyrábal smolu [Krajčovič 2005: 170]. Takýto názov zaznamenávame v nami skúmanej oblasti pri hydronyme Peklianka $(<\mathrm{psl}$. *pъkъlb - smola + príponou -(n)ik). Z predchádzajúceho výkladu je zretel’né, že v súvislosti s etymológiou názvu Smolnik je vhodné vychádzat’ z adjektívneho tvaru smolný + substantiviz. $-i k$. 
Nemeckí kolonisti, ktorí prišli do povodia Smolníka, zväčša preberali už existujúce slovanské názvy vodných tokov a adaptovali ich formu do vlastného jazyka, no utvárali tiež nové názvy. Práve na označenie rieky Smolník si vytvorili vlastný názov *Materský potok (nem. Mutterbach) $(<$ nem. apel. e Mutter - matka $+r$ Bach-potok), pretože vychádzali z geomorfologického reliéfu krajiny, ktorou rieka preteká a vzhl'adom na pomerne väčší onymický objekt ho nazývali hlavným tokom v Smolníckej doline, pričom všetky jeho prítoky predstavovali iba krátke toky. Okrem tohto názvu je dochovaný aj variant *Cementačná voda (nem. Zementwasser $)(<$ nem. apel. $r$ Zement - cement $+s$ Wasser - voda), ktorá súvisí s výrobou cementačnej medi v Smolníku. Ako uvádza I. Chalupecký [1991] značná čast' medi sa získavala cementáciou z banských vôd a bola považovaná za jednu z najkvalitnejších medís. Spišská med’ tavená v hutách v Gelnici, Smolníku a Tichej Vode totiž ovládla v 14. storočí trhy v severnej časti Európy a do sveta sa vyvážala pod názvami göllnitzer, schmöllnitzer a stillbacher kupfer.

V Smolníckej doline neprosperoval iba Smolník, ale aj ostatné osady sa v nej nachádzajúce. Išlo predovšetkým o osadu Smolnícka Huta (nem. Schmöllnitzer-Hütte), ktorej prvé zmienky o osídlení na Smolníckom potoku, ktorý ňou preteká, sú v texte výsadnej listiny Ladislava IV. z roku 1287 [Marsina 1984]. Už v roku 1290, ked' král' určil hranice chotára mesta Gelnica, sa spomína, že v údolí Smolníckeho potoka sú pece, v ktorých sa praži a kalí železo“. Evidentne sa tu naráža na už jestvujúcu obec Smolnícku Hutu, ktorá sa v nemčine nazývala Schmöllnitzer Pochdorf $(<$ nem. verba schmelzen - tavit' rudu + pochen - rozbíjat', drvit' $+s$ Dorf - dedina) a podl'a listiny tu fungovali železorudné bane, drviarne a pražiarne. J. Bartalský [2003: 261] uvádza, že cez pramene potoka Smolník až $k$ železným baniam" sa dostaneme $\mathrm{k}$ hute s pecami, v ktorých sa vyrábala na trhu vel'mi požadovaná, mosadzná med'.

Prichádzajúci Nemci na Spiš sa však neusadili len v okolí Gelnice a v Smolníckej doline, ale aj v oblasti Novoveských vrchov, kde postupne obsadili aj celú Hnileckú dolinu. Sami hostia sa nazývali gründlermi a Hnileckú dolinu nazývali Gründlegebiet. Názov je odvodený od nemeckého slova gründle, čo znamená úzke údolie zavlažené potokmi [Zavatzky 2001]. Ťažisko novoveského baníctva predstavovalo údolie rieky Hnilec a jeho prítoku Železného potoka. Aj pre túto lokalitu

${ }^{4}$ V Smolníku sa okrem dobývania rúd odpradávna vyrábala cementačná med', nakol'ko sa tu funkčne zužitkovala cementačná voda. Cementačnú vodu smolníckeho ložiska tvorili prirodzené alebo umelé roztoky kyseliny sírovej a medených solí, prevažne modrej skalice. Z nich sa med' do pevného stavu vyzrážala pomocou kovového železa, a to najprv v podzemí a potom $\mathrm{v}$ tzv. cementačných zariadeniach na povrchu. Vznik cementačnej vody v ložisku úzko súvisel s exploatáciou úžitkovej suroviny (jej rozrušovaním, uskladňovaním) a postupným sprístupňovaním častí ložiska (pozri bližšie Bartalský 2003: 216-217).

${ }^{5} \mathrm{O}$ spôsobe dolovania a spracovania rudy v smolníckych baniach sa zmienil už aj latinský humanista J. Werner vo svojom diele Krátka správa o podivuhodných vodách Uhorska (Pozri bližšie slovenský preklad in: Škoviera 2008: 161-191. 
je príznačná pevne zakorenená tradícia baníctva a hutníctva, ktorá sa premietla aj pri tvorení názvov vodných tokov. Počiatky baníctva v tejto oblasti sa zhodne s predchádzajúcim regiónom kladú na začiatok stredoveku, ked’ sa ruda tavila $\mathrm{v}$ blízkosti náleziska $\mathrm{v}$ primitívnych pol’ných šachtových peciach za použitia prirodzeného t’ahu, neskôr za pomoci dúchadla. Ked' sa na pohon dúchadiel a kladív začala používat' vodná energia, stavali sa hámre pri vodných tokoch. Už v 15. storočí boli na území Dobšinej pri rieke Hnilec hámre s malými osadami, no ich konkrétne názvy nie sú známe. Uvažujeme, že jedna osada s hámrom bola predchodkyňou Dobšinskej Maše. Údaj z roku 1466 hovorí o existencii hámra na výrobu zbraní [Šlosár 2001]. Roku 1551 Ladislav a Štefan zo Štítnika dali súhlas na stavbu maše a hámru pri Hnilci. Postupne sa stavanie maší (pecí na výrobu železa) rozšírilo aj do d'alších lokalít. Pojmom maša (= huta) sa označovali kusové pece, dúchačky, $\mathrm{v}$ ktorých sa redukciou sideritov vyrábalo surové železo, vhodné na výrobu mečov, šablí, pancierov, aj liatina, z ktorej sa vyrábali pece, platne, rošty, gule do diel a pušiek [Šmelko 2000: 19-20]. V 17. storočí sa rozšírili tzv. maše s rozsiahlejšími a väčšími pecami viac-menej oddelene od kováčskych dielní [Šmelko 2000].

Prvú takúto vysokú pec postavil roku 1680 saský technik Daniel Fischer na Dobšinskej Maši. Práve pri tejto „slovenskej peci“, ako uvádza mašianska kronika, vznikla osada, ktorá sa pred rokom 1891 nazývala „Dobšiná - Hnilecko-dolinská železiarska osada“, po tomto roku Dobšinská Maša [Šlosár 2001: 17-18]. Vznik huty súvisí s Lányho vysokou pecou, postavenou počas povstania Františka II. Rákoczyho. V činnosti bola od roku 1712 a vlastnilo ju mesto Dobšiná, pričom okrem pece patril $\mathrm{k}$ výrobným zariadeniam aj vykúvací hámor [Jančura 2010: 164]. Pri výstavbe vodnej nádrže Palcmanská maša bola osada Dobšinská Maša zatopená a nanovo postavená na jej južnom brehu. V roku 1960 bola spolu s jej dnešnou miestnou čast'ou pripojená k obci Dedinky, hoci pôvodne osada patrila pod správu mesta Dobšiná. Apelatívum „maša“ sa stalo určujúcim motivantom aj pri hydronyme Palcmanská maša, pomenovanie ktorého súvisí s výstavbou huty, pričom do konca 18. storočia sa tu vybudoval celý komplex železiarenských zariadení. Palcmanskú mašu postavili bratia Leopold a Samuel Paltzmannovci, pravdepodobne na mieste starého hámra, založeného ešte v roku 1420 [Šmelko, Novák 2008]. Berúc však na vedomie pôsobenie nemeckého etnika v danej lokalite, vyjadrujeme predpoklad, že pri tomto hydronyme, vzhl'adom na dochovanú najstaršiu nemeckú podobu Paltzman hütte (< OM. Paltzman + e Hütte - huta), možno uvažovat' aj o kalkovaní, pretože ako sme spomenuli, pod apelatívom maša sa rozumela huta na spracovanie rúd. S označením „maša“ sa stretávame aj pri hydronyme Smižianska Maša, ktorú v roku 1803 postavil Štefan Csáky zo Smižian. Podnik sa skladal z vysokej pece, vykúvacieho hámra a dvoch skujňovacích vyhní. Pohon na chod zaobstarávala voda a v podniku sa vyrábalo železo, liatina a zhutňovala sa ruda z ned’alekých spišských baní. Koncom 40. rokov 19. storočia pribudla $\mathrm{v}$ železiarni d’alšia vysoká pec s valcovým dúchadlom, poháňaným parným strojom [Žifčák 1993]. 
Skôr než pristúpime k d’alšej analýze názvov vodných tokov, považujeme za určujúce objasnit' význam apelatíva hámor, ktoré má početné zastúpenie ako motivant hydroným. R. Krajčovič [2005: 195] hámrom označuje dielňu, ktorá pozostávala zo 4 častí: z taviacej pece (huty), z vyhne na zohriatie kovu, dúchadiel a kladív (< nem. apel. $r$ Hammer - kladivo). Všetky časti hámrov používali na pohon dúchadiel alebo kladív vodnú energiu. P. Zámora [2003: 85] uvádza, že hámor predstavoval súčast’ železiarskej huty, v ktorom sa železo vykúvalo na rozličné produkty alebo poloprodukty. Túto súvislost' treba nachádzat' aj pri hydronyme Hámor, ktoré motivovalo ON. Hámre. R. Krajčovič [2005] tvrdí, že mnohé Hámre sú v súčasnosti zemepisne späté s najbližšou obcou, čo možno pozorovat' pri miestnej časti Hámor v samotnej osade Hnilec. Pri spracovaní rúd vznikal hutnícky odpad, ktorý sa v baníckej terminológii označoval ako troska, a práve dané apelatívum sa stalo motivujúcim činitel'om vzniku hydronyma Trosky (> ON. Trosky). Čo sa týkalo technologického postupu pri spracovaní rúd, používali sa stupy $(>$ VN. Stupy $>$ ON. Stupy), ktoré predstavovali primitívne strojové zariadenie používané na drvenie tvrdých hmôt a rúd, pričom v ich blízkosti sa nachádzali aj premývačky na ich vodnú úpravu [Šmelko 2008: 27]. Získaná ruda sa teda $v$ prvopočiatkoch drvila, separovala, mlela najskôr ručne, neskôr využitím vody v stupách, postavených pri každej väčšej bani. Tento postup spracovania našiel svoj odraz pri hydronyme Mlynky, ktorého motivantom sa stali rudné mlyny, ktoré vodou poháňali zariadenia zomiel'ajúce rudu [Šmelko 2008].

Aby sa baníctvo mohlo v skúmanej oblasti povodia Hornádu vôbec rozvinút', museli sa tu nachádzat' bohaté náleziská rúd. Dané apelatívum je doposial' dochované v názvoch vodných tokoch, ktoré explicitne poukazujú na mimojazykovú skutočnost', bezprostredne spätú s dolovaním nerastných surovín. Historicky doložené apelatívum ruda nachádzame pri dvoch hydronymách Rudník (< apel. ruda $<$ psl. *ruda + suf. -(n)ík), ktorých názov motivovala t’ažba rúd v oblasti, ktorou potok preteká. V povodí Hornádu evidujeme aj hydronymum Rudniansky potok, ktoré je síce tiež utvorené z apelatíva ruda, no ide o názov novší, súvisiaci so zmenou osadného názvu Koterbachy na Rudňany (1948). Okrem toho z roku 1255 nachádzame doklad Kuffurbach $(<$ nem. s Kupfer - med' $+r$ Bach - potok $=$ Medený potok $)$, neskôr Kotterbach $(<$ nem. $r$ Kot - blato $+r$ Bach - potok $=$ Blatný potok).

Pri banskom t’ažení sa dolovali aj drahé kovy ako zlato, striebro, med' a železo. Práve spomenuté nerastné rudy sa stali motivantami pri tvorení názvov vodných tokov pretekajúcimi oblast’ou charakteristickou t’ažbou týchto kovov. Analýzou pestrej palety hydroným sme zistili, že apelatívum zlato podnietilo vznik až štyroch zhodných názvov vodných tokov Zlatník, ktorého názov súvisí s tým, že sa v minulosti v potoku ryžovali, vymývali zlaté zrnká. Ťažba a dolovanie železnej rudy zase motivovala vznik názvu Železného potoka, ktorého minerálna a termálna kultúra obsahuje oxid uhličitý. Pri tomto hydronyme je na mieste opätovne uvažovat', či súčasný štandardizovaný názov nevznikol kalkovaním zo staršie- 
ho nemeckého dokladu EisenBach ( $<$ nem. apel. $s$ Eisen - železo $+r$ Bach - potok), ktorý sa na mapách vyskytoval až do roku 1939. Výskytom medi v lokalite, ktorou potoky pretekali, boli motivované názvy Medený potok $a$ Kopagrund $(<s$ Koppa - med' $+r$ Grund - dolina).

\section{Záver}

Vychádzajúc z ilustrovaných hydroným na území Spiša je viditel'né, že banícka a hutnícka činnost', už z predslovanských čias, zanechala svoju pečat' aj v názvoch vodných tokoch. $K$ rozvoju odbornej terminológii však dochádza až v súvislosti s príchodom prvých nemeckých kolonistov, ktorí dopín̆ali rady slovanských rudníkov a hutníkov v Smolníckej a Hnileckej doline. Existujúce a v komunikácii dobre fungujúce názvy vodných tokov prichádzajúci Nemci bud' od Slovanov prebrali alebo vytvorili nové názvy, úzko súvisiace s vykonávanou baníckou, resp. hutníckou činnostou. Následne tak cudzojazyční pisári kvôli orientácii adaptovali jestvujúci (slovanský) názov po formálnej stránke, pričom sa usilovali zachovat' obsah názvu. Ak hydronymum nedokázali reprodukovat', uvádzali slovanský originál názvu. $Z$ toho dôvodu aj v neskoršom nemeckom kolonizačnom prostredí východoslovenských banských miest máme dochovanú najstaršiu vrstvu slovanských pomiestnych názvov.

\section{Bibliografia}

Bartalský, Ján a kol., 2003, Smolník. Mesto medenorudných baní, Bratislava.

Budinský-Krička Vojtech, 1965, Staroslovanské obdobie, [in:] Pravek východného Slovenska VIII/1, Košice, 211-249.

Furmánek Václav, Ruttkay Alexander, Šiška Stanislav, 1991, Dejiny dávnovekého Slovenska, Bratislava.

Huňák Ladislav a kol., 1988, 40 rokov Železorudných baní Spišská Nová Ves, Spišská Nová Ves.

Chalupecký Ivan, 1991, Východoslovenské banské mestá, „Vlastivedný časopis“ XXXX, č. 1, 28-31.

Jančura Marián, 2010, Baníctvo mesta Spišská Nová Ves, Spišská Nová Ves.

Krajčovič Rudolf, 2005, Živé kroniky slovenských dejín skryté v názvoch obci a miest, Bratislava.

Marsina Richard, 1984, O osídleni Slovenska od 11. storočia do polovice 13. storočia, [in:] Historické štúdie. Slovenský l’ud po rozpade Vel'komoravskej ríše, Bratislava, 39-61.

Pastor Ján, 1955, Východné Slovensko na úsvite dejín, [in:] Vlastivedný sborník I, Košice, 122-143.

Piirainen Ilpo Tapani, Meier Jörg, 1993, Das Stadtbuch von Schwedler/Švedlár : Texte und Untersuchungen zum entstehenden Neuhochdeutsch in der Slowakei, Levoča.

Pöss Ondrej, 2000, Karpatskí Nemci, „Pamiatky a múzeá“ 49, č. 4.

Pravek východného Slovenska, 1965, Vojtech Budinský-Krička a kol. (eds.), Košice.

Ratkoš Peter, Mesto Smolnik v stredoveku, „Historické štúdie“ IX, 77-84.

Rešovský Jozef a kol., 2010, Demografický vývoj okresov Spišská Nová Ves a Gelnica v rokoch 1998-2007, Spišská Nová Ves. 
Šlosár Ján, 2001, Dedinky, Dedinky.

Šmelko Leopold a kol., 2000, Mlynky, Mlynky.

Šmelko Leopold, Novák Emil, 2008, Baníckou a lyžiarskou stopou, Mlynky.

Šmilauer Vladimír, 1932, Vodopis starého Slovenska, Praha-Bratislava.

Varsik Branislav, 1990, Slovanské (slovenské) názvy riek na Slovensku a ich prevzatie Mad'armi v 10.-12. storoči. Príspevok k etnogenéze Slovákov, Bratislava.

Vencko Ján, 1941, Z dejín okolia Spišského hradu, Spišské Podhradie.

Werner Juraj, 2008, Krátka správa o podivuhodných vodách Uhorska, [in:] Latinský humanizmus, Bratislava, 163-191.

Zámora Peter, 2003, Dejiny baníctva na Slovensku. 1. Diel, Košice.

Zavatzky Gunter, 2001, Mníšek nad Hnilcom, Sabinov.

Žif̌ća František a kol., 1993, Smižany, Smižany.

\title{
Andrea Goótšová
}

\section{Mining and metallurgical tradition in the Spis region and its reflection in the hydronymia of the Hornád River basin}

\author{
(Summary)
}

The paper draws attention to an attempt to clarify a long-lasting tradition of mining and metallurgy in the Spis region. Taking into account the arrival of German miners and metallurgists and the background of a historical development, the names of water streams in the Smolnik and Hnilec valley are being described. The professional terminology related to their activities which left its impact on hydronyms have become the subject of our analysis.

Słowa kluczowe: górnictwo, hutnictwo, spisy regionalne, hydronim, motywacja.

Key words: mining, metallurgy, Spis region, hydronyms, motivation. 